\title{
EHMTI-0068. Facial plastic surgery for migraine therapy: personal procedures
}

\author{
G Caruana*, N Bertozzi, MP Grieco, E Raposio \\ From 4th European Headache and Migraine Trust International Congress: EHMTIC 2014 \\ Copenhagen, Denmark. 18-21 September 2014
}

\section{Background}

During the last few years multiple studies have demonstrated the efficacy of surgical treatment in patients who suffer from migraine headache: by removing the hyperactive surrounding muscles, the trigger point is being eliminated.

\section{Aim}

The aim of this study was to demonstrate the efficacy of surgical decompression by means of both endoscopic and open surgery, through an innovative and improved technique compared with beforehand evaluated surgical techniques.

\section{Method}

Fifty-one patients who complained of chronic migraine headaches underwent a frontal bilateral selective miotomy procedure of Procerus, Depressor Supercilii and Corrugator Supercilii Muscles by means of videoassisted endoscopic surgery, and/or an occipital selective miotomy procedure of Occipital, Trapezius, Sternocleidomastoid and Semispinalis Capitis Muscles by means of open surgery.

\section{Results}

Of the 51 patients included in the study (range, 18 to 73 years), 38 were women and 13 were men. Forty-four of 51 patients $(86.3 \%)$ reported a positive response to the surgery: 21 of 51 patients (41.2\%) observed complete elimination, 23 patients (45.1\%) experienced significant improvement (at least 50\% reduction in intensity or frequency), and 7 patients (13.7\%) did not notice a change in their migraine headaches.

Surgical Science, University of Parma, Parma, Italy

\section{Conclusion}

This study confirms previous data in literature, strengthening the role of a peripheral mechanism (trigger points) in migraine headaches. Moreover, the minimally invasive procedure we described, is easy, fast and cost-effective, relying on the use of a single instrument, also reducing the numbers of postoperative scars from five to one.

No conflict of interest.

Published: 18 September 2014

doi:10.1186/1129-2377-15-S1-G6

Cite this article as: Caruana et al:: EHMTI-0068. Facial plastic surgery for migraine therapy: personal procedures. The Journal of Headache and Pain 2014 15(Suppl 1):G6.

\section{SpringerOpen ${ }^{\circ}$}

(c) 2014 Caruana et al; licensee Springer. This is an Open Access article distributed under the terms of the Creative Commons Attribution License (http://creativecommons.org/licenses/by/2.0), which permits unrestricted use, distribution, and reproduction in any medium, provided the original work is properly cited.
Submit your manuscript to a SpringerOpen ${ }^{\circ}$ journal and benefit from:

- Convenient online submission

- Rigorous peer review

- Immediate publication on acceptance

- Open access: articles freely available online

- High visibility within the field

- Retaining the copyright to your article

Submit your next manuscript at $>$ springeropen.com 